\title{
In Memory of Yurii Pavlovich Zelinsky (January 28, 1947 to January 10, 2007)
}

DOI: $10.1134 / \mathrm{S} 0032945207090160$

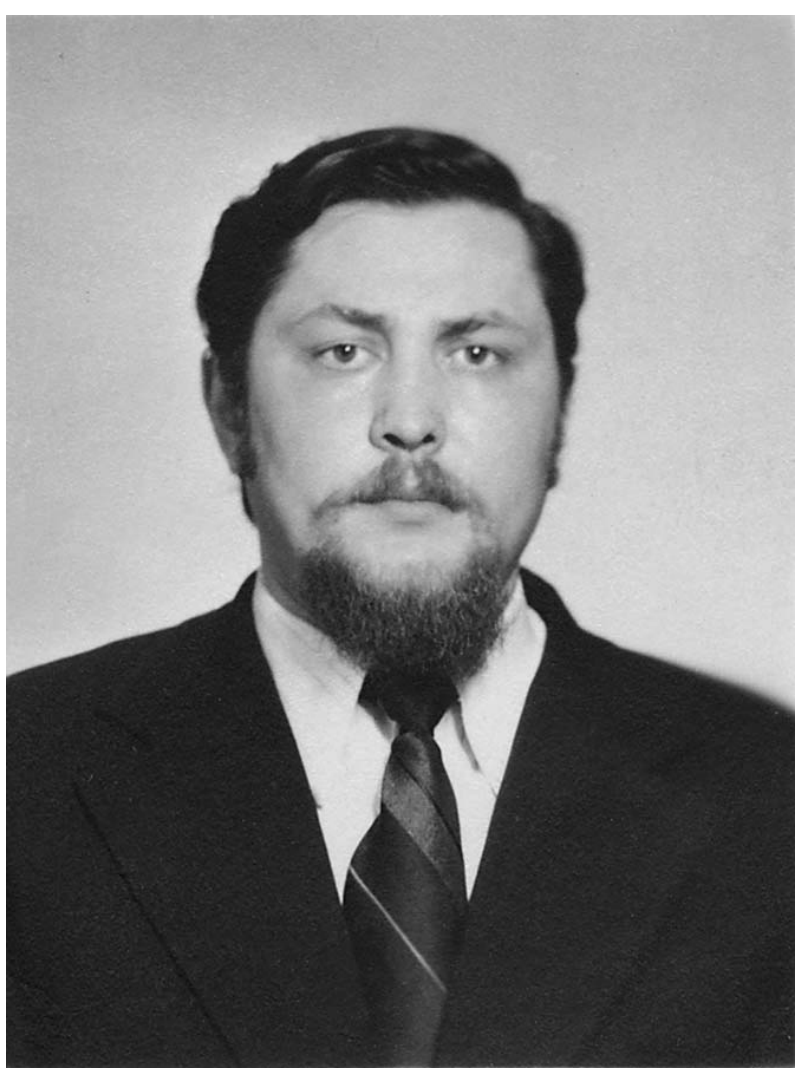

Yu.P. Zelinsky was born in Karelia, in Belomorsk. This small, highly distinctive town is located at the mouth of the Vyg, a famous salmon river. The remarkable fish called semga by coast dwellers and the Atlantic salmon, by ichthyologists of the world, became the main object of study of the researcher.

As early as during his study at Petrozavodsk University (1966-1971), he participated in integrated studies of Atlantic salmon performed at the Laboratory of Ecology of Fish and Aquatic Invertebrates of the Institute of Biology of the Karelian Branch of the USSR Academy of Sciences (Now, the Karelian Research Center of the Russian Academy of Sciences).

Later during his postgraduate studies at Moscow State University, headed by the USSR Academy of Sciences Corresponding Member G.V. Nikolsky, Zelinsky used methods of morphological and karyological analysis for studying the ways of dispersal of Atlantic salmon into the southern part of the White Sea Basin from the Baltic Basin. Data obtained during recent years using novel molecular-genetic methods confirmed his hypothesis.

After postgraduate studies, Zelinsky continued to work at the Karelian Branch of the USSR Academy of Sciences. Many years of labor-expeditions, scrupulous treatment of the material, and analysis of multilingual literature-enabled him to prepare a monograph on Atlantic salmon (Zelinsky, 1985) that is actively used by specialists to this day. In this paper, the researcher generalized a vast amount of data. Besides, he advanced a bold suggestion concerning the origin of the karyotype of the Atlantic salmon as a result of simultaneous fusion of several chromosomes of the ancestral species-brown trout.

This idea enabled Zelinsky to regard the evolution of all Salmonoidei in a new way. He collected and treated increasingly new samples of salmonids, coregonids, and graylings and analyzed world literature on the karyotypes of these fish. Three homological series including species of different families with the number of chromosomes about 60,80 , and 100 became increasingly distinct. The pioneer of these series, G. Svardson considered them polyploid series; however, this assumption was not confirmed. Zelinsky gave another explanation: series are formed due to simultaneous fusion of several chromosomes. As a result, of species with 100 chromosomes, species with 80 chromosomes originate, and of them, are species with 60 chromosomes.

The existence of these homological series causes no doubts in specialists. It seems to us possible to name them the Svardson-Zelinsky series in honor of their pioneer and in honor of a researcher who explained the reason of their emergence.

Zelinsky was interested not only in Salmonoidei; he began studies of other fish groups that emerged via polyploidy-cyprinids and acipenserids. The researcher planned to prepare a comprehensive work on regularities of the evolution of groups of fish of polyploid origin.

At the same time, Zelinsky did not limit himself to the study of fundamental problems. The studies of karyotypes provided him arguments that enabled him to protest against the insistently advocated idea about the belonging of two groups of Pacific salmon-Parasalmo and Oncorhynchus - to one genus. He was among 
those who first raised the problem of protection of the gene pool during artificial reproduction of salmon. Under the severe conditions of the early 1990s, he managed to organize several expeditions to regions of difficult access and collected, kept in liquid nitrogen, and delivered to genetic banks the samples of sperm of several rare forms of Salmonidae.

Unfortunately, the blow inflicted to our science by perestroika strongly affected Zelinsky also. The organization of expeditions, the search for needed equipment, reagents, and finances required much energy and time. The health of the researcher was shaken, and he was induced to leave the native North and to begin to work at the Tula Pedagogical Institute. In Tula, Zelinsky continued to struggle with a tangle of severe diseases and, until his last days, did not stop his scientific work.

He had an opportunity to see the results of his numerous followers. The study of the gene pool of Russian populations of Atlantic salmon initiated by Zelinsky is continued at the present time by several Russian and foreign (Scottish, Norwegian, Finnish) specialists. Homological series by the number of chromosomes in Salmonoidei-the SvardsonZelinsky series - are intensively studied too.

\section{A.A. Makhrov (IOGen RAN), Yu.A. Smirnov (Branch Karel'skii OAO TGK-1), V.A. Shirokov (SevNIIRKh PetrGU), I.L. Shurov (SevNIIRKh PetrGU)}

\section{THE LIST OF MAIN SCIENTIFIC WORKS OF YURII PAVLOVICH ZELINSKY}

Zelinsky, Yu.P., "Some Indices of Cytogenetic Analysis of Reproductive Systems of Migratory and Dwarf Males of Atlantic Salmon Salmo salar L.," in Lososevye Karelii (Salmonidae of Karelia), Petrozavodsk: Institute of Biology, Karelian Branch of the USSR Academy of Sciences, 1976, pp. 35-41.

Zelinsky, Yu.P., "Osteological Differentiation and Some Issues of Genesis of Migratory and Lacustrine Populations of Atlantic Salmon Salmo salar in Basins of the White and Baltic Seas," Vopr. Ikhtiol., 1976, vol. 16, no. 2, pp. 283-295.

Zelinsky, Yu.P., "Chromosome Sets of Atlantic Salmon Salmo salar L. of the Resident Population from Kuito Lakes (the White Sea Basin)," Vopr. Ikhtiol., 1976, vol. 16, no. 6, pp. 1119-1124.

Zelinsky, Yu.P., "Morphological Specific Features of Migratory and Lacustrine Populations of Atlantic Salmon Salmo salar L. from the White and Baltic Seas," Candidate's Dissertation in Biology, Moscow: Mosk. Gos. Univ., 1977.

Zelinsky, Yu.P., "On Commercial Return of Atlantic Salmon of Hatchery Reproduction," Rybn. Khoz., 1979, no. 11, pp. 30-31.

Zelinsky, Yu.P., "Chromosome Analysis of the Population of Atlantic Salmon from Ladoga Lake," Zool. Zh., 1980, vol. 59, no. 8, pp. 1260-1263.

Zelinsky, Yu.P., "Karyotypes of Populations of Atlantic Salmon from the Kert and Pechora Rivers," in Kariologicheskaya Izmenchivost', Mutagenez i ginogenez u ryb (Karyological Variation, Mutagenesis, and Gynogenesis in
Fish), Leningrad: Nauka, 1980, pp. 10-15 (in coauthorship with Svimonishvili, T.N. and Gorodilov, Yu.N.).

Zelinsky, Yu.P., "Variation in Chromosome Sets of Atlantic Salmon Salmonidae) of Karelia," in Lososevye (Salmonidae), Petrozavodsk: Institute of Biology, Karelian Branch of the USSR Academy of Sciences, 1983, pp. 126-129.

Zelinsky, Yu.P., "Karyotype and Formation of Adaptations of Freshwater Char-Lake Char of the Genus Salvelinus (Salmoniformes, Salmonidae) from Ladoga Lake," Zool. Zh., vol. 62, no. 5, pp. 732-736. (in coauthorship with Polina, A.V. and Medvedeva, I.M.).

Zelinsky, Yu.P., Struktura i differentsiya populyatsii i form atlanticheskogo lososya (Structure and Differentiation of Populations and Forms of Atlantic Salmon), Leningrad: Nauka, 1985.

Zelinsky, Yu.P., "On the Analysis of Chromosome Variation and Polymorphism of Atlantic Salmon Salmo salar (Salmonidae) (Population from Onega Lake)," Vopr. Ikhtiol., 1985, vol. 25, no. 2, pp. 212-219. (in coauthorship with Medvedeva, I.M.).

Zelinsky, Yu.P., "Specific Features of Size-Age Indices and Structure of Scales of Spawners of Atlantic Salmon Salmo salar L. from Keret and Kola Rivers," Sb. Nauchn. Tr. Nauchno-Issled. Inst. Ozern. Rechn. Rybn. Khoz., 1986, issue 253, pp. 54-67. (in coauthorship with Safronova, T.V.). Zelinsky, Yu.P., "Issues of Protection of the Gene Pool during the Intensification of Commercial Use of Stock of Atlantic Salmon," in Voprosy lososevogo khozyaistva na Evropeiskom Severe (Issues of Salmon Husbandry in the European North), Petrozavodsk: Institute of Biology, Karelian Branch of the USSR Academy of Sciences, 1987, pp. 5-8. (in coauthorship with Smirnov, Yu.A.).

Zelinsky, Yu.P., "Analysis of Some Issues of Phylogeny, Divergence, and Zoogeography of Salmonids of the Genus Hucho and Atlantic Salmon (Salmo)," Sb. Nauchn. Tr. Nauchno-Issled. Inst. Ozern. Rechn. Rybn. Khoz., 1992, issue 304, pp. 217-229.

Zelinsky, Yu.P., "On Assessment of Variation in Alleles of the Ldh-5 Locus during the Analysis of the Structure of the Sample of the Trout Salmo trutta Adapted to Humification," Vopr. Ikhtiol., 1992, vol. 32, no. 5, pp. 57-62. (in coauthorshop with Gruzdev, A.I.).

Zelinsky, Yu.P., "On Some Estimates of Genome Interactions Based on Results of Study of Specific Features of Growth and Karyological and Morphological Characters of Back Triploid Hybrids of the Goldfish with Carp Cultivated under Conditions of Karelia," Vopr. Iktiol., vol. 32, no. 1, pp. 103-110. (in coauthorship with Dmitrienko, Yu.Yu. and Pervozvanskii, V.Ya.).

Zelinsky, Yu.P., "Chromosomal Variability, Genome Reorganization in Phylogenesis, and the Systematics of Salmo and Parasalmo Species (Salmonidae)," Vopr. Ikhtiol., 2001, vol. 41, no. 2, pp. 184-191. (in coauthorship with Makhrov, A.A.) [J. Ichthyol., 2001, vol. 41, no. 3, pp. 209-216. (in coauthorship with Makhrov, A.A.).

Zelinsky, Yu.P., "Homological Series by Chromosome Number and the Genome Rearrangements in the Phylogeny of Salmonoidei," Russ. J. Genet., 2002, vol. 38, no. 10, pp. 1115-1120. (in coauthorship with Makhrov, A.A.) [Russ. J. Genet., 2002, vol. 38, no. 10, pp. 115-1120].

Zelinsky, Yu.P., "Genome Divergence by the Amount of DNA, Ratio of the Number of Macro- and Microchromosomes in Postpolyploid Evolution of Acipenserids and Factors of Preservation of Their Genetic Resources," Tsitologiya, 2004, vol. 46, no. 9, pp. 795. 